\title{
IODP Deep Biosphere Research Workshop report - a synthesis of recent investigations, and discussion of new research questions and drilling targets
}

\author{
B. N. Orcutt ${ }^{1}$, D. E. LaRowe ${ }^{2}$, K. G. Lloyd ${ }^{3}$, H. Mills ${ }^{4}$, W. Orsi ${ }^{5}$, B. K. Reese ${ }^{6}$, J. Sauvage ${ }^{7}$, J. A. Huber ${ }^{8}$, \\ and J. Amend ${ }^{2}$ \\ ${ }^{1}$ Bigelow Laboratory for Ocean Sciences, East Boothbay, ME 04544, USA \\ ${ }^{2}$ University of Southern California, Los Angeles, CA 90089, USA \\ ${ }^{3}$ University of Tennessee, Knoxville, TN 37996, USA \\ ${ }^{4}$ University of Houston-Clear Lake, Houston, TX 77058, USA \\ ${ }^{5}$ Woods Hole Oceanographic Institution, Woods Hole, MA 02543, USA \\ ${ }^{6}$ University of Southern California, Los Angeles, CA 90089, USA \\ ${ }^{7}$ Graduate School of Oceanography, University of Rhode Island, Narragensett, RI 02882, USA \\ ${ }^{8}$ Marine Biological Laboratory, Woods Hole, MA 02543, USA
}

Correspondence to: B. N. Orcutt (borcutt@bigelow.org)

Received: 5 November 2013 - Revised: 30 December 2013 - Accepted: 7 February 2014 - Published: 29 April 2014

\begin{abstract}
During the past decade, the IODP (International Ocean Discovery Program) has fostered a significant increase in deep biosphere investigations in the marine sedimentary and crustal environments, and scientists are well-poised to continue this momentum into the next phase of the IODP. The goals of this workshop were to evaluate recent findings in a global context, synthesize available biogeochemical data to foster thermodynamic and metabolic activity modeling and measurements, identify regional targets for future targeted sampling and dedicated expeditions, foster collaborations, and highlight the accomplishments of deep biosphere research within IODP. Twenty-four scientists from around the world participated in this one-day workshop sponsored by IODP-MI and held in Florence, Italy, immediately prior to the Goldschmidt 2013 conference. A major topic of discussion at the workshop was the continued need for standard biological sampling and measurements across IODP platforms. Workshop participants renew the call to IODP operators to implement recommended protocols.
\end{abstract}

\section{Introduction to Deep Biosphere Objectives in IODP}

Scientific ocean drilling is entering its 48th year and is poised to continue creating momentous breakthroughs in the understanding of Earth processes. Four challenges have been set forth by the drilling community as the best opportunities for rapid achievement of transformative science: climate and ocean change; Earth connections; Earth in motion; and biosphere frontiers (IODP, 2011). Interdisciplinary science has been the foundation of the drilling program, and recently deep biosphere science has been recognized as a significant contributor in addressing questions across all themes, particularly climate and ocean change. It was specifically noted during the 2012 Building US Strategies Workshop that many scientists who do not directly identify their research as relevant to biosphere frontiers are nevertheless interested in biosphere challenges and would sail, request data, or apply others' results to their research. The priorities within biosphere frontiers challenge address questions such as What are the origin, composition, and global significance of subseafloor communities? What are the limits of life in the subseafloor? How sensitive are ecosystems and biodiversity to environmental change?

Several IODP (International Ocean Discovery Program) expeditions have focused on testing specific hypotheses 
regarding factors that control the distribution, community composition, and activities of the deep biosphere in a diverse array of subseafloor environments. These environments included a near-shore upwelling regime (Expedition 201: Peru Margin), extremely low-energy sediments (Expedition 329: South Pacific Gyre and Expedition 336: North Pond), oceanic crust (Expeditions 301 and 327: Juan de Fuca Ridge, and Expedition 336: North Pond), near-hydrothermal vents (Expedition 331: deep hot biosphere), a carbon-rich environment (Expedition 337: deep coalbed biosphere off Shimokita), and, most recently, the Baltic Sea paleoenvironment (Expedition 347). These expeditions demonstrate the rapid growth of deep biosphere research and the critical contributions provided by scientific ocean drilling. They also highlight the fact that deep biosphere investigations are not platform-specific, but can be adapted for IODP expeditions on the RV JOIDES Resolution, RV Chikyu, or on missionspecific platforms. These recent advances and expeditions prompted a call for a workshop to synthesize new findings in a global context, and to identify obstacles to new discoveries.

\section{Recent deep biosphere discovery highlights}

Since the incorporation of sterile sampling techniques in 2001, ODP (Ocean Drilling Program) and IODP expeditions have produced a wealth of high-impact discoveries about the subsurface biosphere. The largest leap forward was simply the discovery that microorganisms (archaea and bacteria) are present, intact, and metabolically active in uncontaminated deep subsurface sediments (Parkes et al., 2005; Schippers et al., 2005; Biddle et al., 2006; Morono et al., 2011). Not only are they present, but also they are taxonomically diverse, and include many new deep evolutionary branches on the tree of life (Schippers et al., 2005; Biddle et al., 2006; Inagaki et al., 2006). The growing library of deep subsurface sedimentary cell count measurements has enabled the most refined estimate of the total amount of subsurface life to date, showing this vast ecosystem to rival the microbial biomass of all the oceans (Kallmeyer et al., 2012). More recent IODP expeditions have given the first glimpses into life in sediments with very low deposition rates and with little access to photosynthetically derived detrital food sources. Small populations of slowly metabolizing microorganisms nonetheless continue to drive diagenetic processes in these extremely harsh environments (D'Hondt et al., 2009; Røy et al., 2012). These findings represent a major breakthrough in our understanding of how life can be sustained by alternative energy sources, possibly fueled by the radiolysis of water (Blair et al., 2007). Life, therefore, is not forced to conform to the energy-rich habits provided by surface photosynthetic conditions. Other IODP expeditions have shown that life exists in the subseafloor oceanic crust (Mason et al., 2010; Lever et al., 2013), suggesting that samples from even deeper below the subfloor will yield countless new discoveries.

With only a handful of microbiology-based drilling expeditions to date, subseafloor microbiology and biogeochemistry studies have made transformative discoveries that have added a new level of understanding to biological and chemical oceanography. Active microbial metabolism in the subseafloor is now known to proceed over geological timescales (D'Hondt et al., 2002, 2004; Orcutt et al., 2011; Lomstein et al., 2012; Lever et al., 2013), in sediment that is up to 86 million years old (Røy et al., 2012). Genomic, metagenomic and metatranscriptomic data sets from the subseafloor have allowed for metabolic rate calculations and measurements to be placed in a microbiological context (Biddle et al., 2008; Mills et al., 2012; Lloyd et al., 2013; Orsi et al., 2013b). New techniques for assessing the activity and whole genomic material from individual microbial cells have opened up the possibility of discovering new capabilities in living native subsurface cells (Morono et al., 2011; Lloyd et al., 2013), and by employing new chemical indicators for sporulated cells, researchers now have the tools to distinguish between dormant and metabolically active populations (Lomstein et al., 2012). Finally, the third domain of life, Eukarya (specifically fungi), is also now known to be active in the subseafloor and, likely, to play an important role in the degradation of organic matter in subseafloor sediment (Biddle et al., 2005; Edgcomb et al., 2011; Orsi et al., 2013a). Such studies have fostered a new level of understanding of subseafloor microbiology and have laid the foundation for future investigations of important subseafloor microbial processes.

\section{Using geochemical and geophysical data to constrain microbial activity}

Although the ubiquity of active microorganisms in marine deep sediments has been confirmed, it is not yet clear exactly what they are doing or how fast they are doing it (Jørgensen, 2011). One approach to constraining answers to these questions is to use quantitative models that employ the physical and chemical data that describe sedimentary ecosystems. For example, temperature, pressure, and compositional information reported for particular environments can be combined with thermodynamic data to calculate the amount of energy available to microorganisms in sediments, and from what reactions this energy comes. The hypothesis guiding these calculations is that the reactions that are the most energyyielding in a particular environment are most likely to be catalyzed by resident microorganisms. These kinds of calculations have been carried out to varying extents in deepsea sediments located in the Bay of Bengal (Schrum et al., 2009), Guaymas Basin, and the Black Sea (LaRowe et al., 2008), Peru Margin (Biddle et al., 2006; Wang et al., 2010; LaRowe and Amend, 2014), the Gulf of Mexico (Joye et al., 2009), the South Pacific Gyre (LaRowe and Amend, 2014), 
the Juan de Fuca Ridge (LaRowe and Amend, 2014), and the Juan de Fuca Ridge flank (Lever et al., 2010). In a related study, the energetic potential of iron and sulfur-bearing minerals from a number of DSDP/ODP drill sites was also quantified (Bach and Edwards, 2003). The limitation of this thermodynamic approach is that the results of these calculations only reveal the amount of energy that is available from the reactions for which there are sufficient chemical data, and nothing is determined about whether these reactions actually occur, and, if so, at what rates.

A complementary approach to understanding microbial behavior in the deep biosphere utilizes reaction-transport models (RTMs) that relate depth-dependent compositional trends observed in sediments to the rates of diffusion, advection and abiotic and microbially mediated reactions. Although RTMs have been applied to explain the driving forces shaping numerous ecosystems, few have been used to quantify the activity of microorganisms in marine deep sediments. Notable exceptions include models applied to sediments from the Demerara Rise (Arndt et al., 2006) and the eastern equatorial Pacific (Wang et al., 2008). A RTM has recently been applied to quantify the rates of microbial catabolism in deep-sea hydrothermal vent chimneys (LaRowe et al., 2014), and similar types of models were used to constrain oxygen consumption patterns in upper oceanic crust (Orcutt et al., 2013) and North Pacific Gyre (Røy et al., 2012). Both bioenergetic and RTM strategies for understanding the deep biosphere functions are restricted by the availability of physiochemical data produced by the IODP. However, as more IODP sites are microbiologically characterized, the resulting physiological and biomolecular data can be used in a complementary fashion with modeling techniques. The archiving of geochemical data in databases such as SEDIS (Scientific Earth Drilling Information Service) is critical for these types of models, and archival of related microbiological data in common databases should be a priority for the deep biosphere community. Importantly, it is clear that deep biosphere scientists need to work closely with scientists from other disciplines, such as geophysics and geochemistry, to assemble and understand the environmental conditions and constraints on microbial activity.

\section{On the horizon}

Future studies of subseafloor microbiology will build upon IODP's foundation by taking advantage of the rapid evolution in DNA and RNA sequencing technology, e.g. the "genomic revolution". The average cost of sequencing a bacterial genome is now under USD 1000, one million bases of DNA data can be obtained for less than USD 1, and sequencing technologies are continuously improving. Furthermore, advances in preservation methods for biological material, such as the new sampling freezing technologies, promise to greatly enhance recovery of DNA, RNA, and other biomolecules from cryogenically frozen samples. These genomic approaches are appealing due to the high throughput and high data: cost ratio, but they only truly become relevant and potentially transformative when paired with biogeochemical measurements and models of important microbial processes (e.g. carbon oxidation rates, oxygen/nitrate/iron/manganese/sulfate reduction rates, methanogenesis, and organic matter remineralization). Moreover, because the cost of DNA sequencing is no longer the ratedetermining step for DNA- and RNA-based studies, careful consideration of sampling design should be made when studying the spatial ecology of subseafloor microbes. For example, it is now possible to easily barcode and sequence hundreds of samples in parallel, obtaining hundreds of thousands of DNA sequence reads for each sample. Thus, microbial ecologists can now produce biological replicates, and scale up the sampling efforts for spatially relevant studies. The rate-determining step for DNA and RNA sequence-based studies has shifted from data production to data analysis. Innovative methods will need to be developed to get the most out of sequence databases to use them to their maximum advantage, and to use genetic information to catalyze new hypotheses for direct testing in the hard-to-reach subsurface ecosystem. This is an exciting time because microbial ecology studies can now utilize sampling designs and scales similar to those used in more traditional fields of ecology (e.g. botany and zoology), to reach a deeper level of understanding of subseafloor microbial ecology and of how distributions and activities are linked to in situ geochemistry and geology across different subseafloor provinces.

Furthermore, there is increasing awareness that efforts to enrich and cultivate rare and dominant deep biosphere species are needed in order to understand growth rates and adaptation strategies for members of the marine deep biosphere. The increasing sophistication of laboratory assets on the RV JOIDES Resolution and RV Chikyu for enabling shipboard cultivation and microbiological studies has greatly enhanced these efforts, and more developments in this area would be beneficial. Cultivation efforts on mission-specific platforms are somewhat limited, however, due to limited suitable laboratory space and equipment for such work.

\section{Recommendations}

The potential for major discoveries in the field of subsurface biogeochemistry/microbial ecology is significant given the large number of active early-career researchers, the prominence of research objectives within the new IODP 10-year science plan, and large organizations dedicated to deep biosphere research, including the Center for Dark Energy Biosphere Investigations (C-DEBI, funded by the US National Science Foundation) and the Deep Carbon Observatory (funded by the Sloan Foundation). The enthusiasm of early-career researchers in this field was demonstrated 


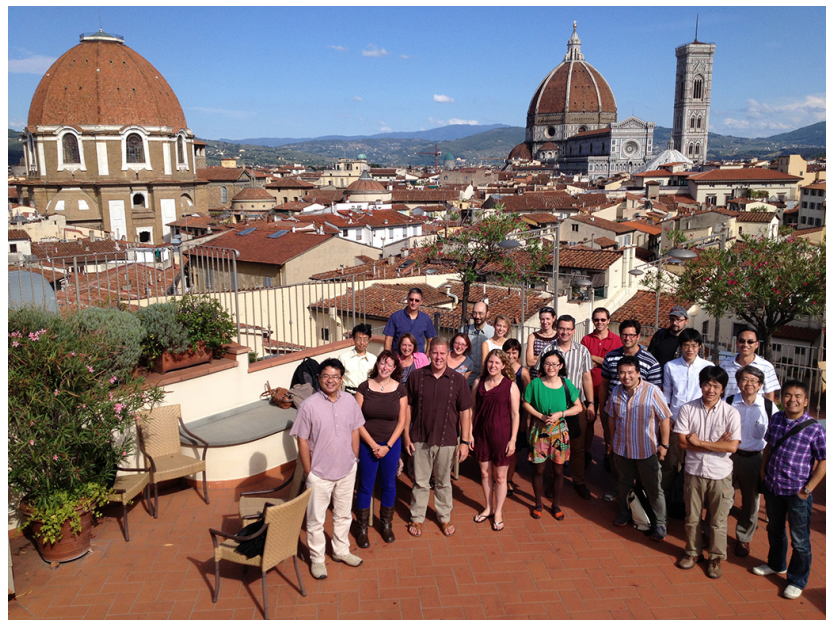

Figure 1. Participants in the IODP Deep Biosphere Workshop at the Grand Hotel Baglioni in Florence, Italy, on 25 August 2013. Not pictured: Steve D’Hondt, Kai-Uwe Hinrichs.

during the IODP Deep Biosphere Research Workshop, in which the participants recognized the immediate importance of establishing standardizing routine contamination testing of core material, sampling core material at regular intervals for archival storage, and immediately performing cell counts during shipboard operations. While deep biosphere research builds on a rich history of biogeochemical studies within ODP-IODP, from over 800 sites drilled during the course of the ODP-IODP programs, only 31 sites (during 10 expeditions) have been properly sampled, documented and archived for multiple microbiological assays, such as DNA extraction, cell counts, and cultivation studies (Fig. 2). Despite this small percentage of sites, the large number of transformative discoveries in deep biosphere research resulting from these samples is remarkable; only a few of the notable papers are listed at the beginning of this report. Thus, continued and additional microbiological sampling on future drilling expeditions is likely to result in even more transformative research on deep life. The proper collecting, processing and preserving of core material using biologically sensitive techniques was seen as essential to ensure adequate access of samples to both the shipboard and shore-based scientists. Several long-term goals were also discussed, including the identification of a common nucleic acid extraction protocol and the selection of specific genes/primers for targeted molecular characterizations. We determined that future discussions with a broader audience would be required to establish these standards. However, success in establishing such protocols should be considered a high priority, as they will facilitate the construction of data sets comparable between expeditions and provide the needed linkage between individual efforts made by our growing community.

During workshop discussions, it was noted that similar recommendations for standard and routine sampling, addi-

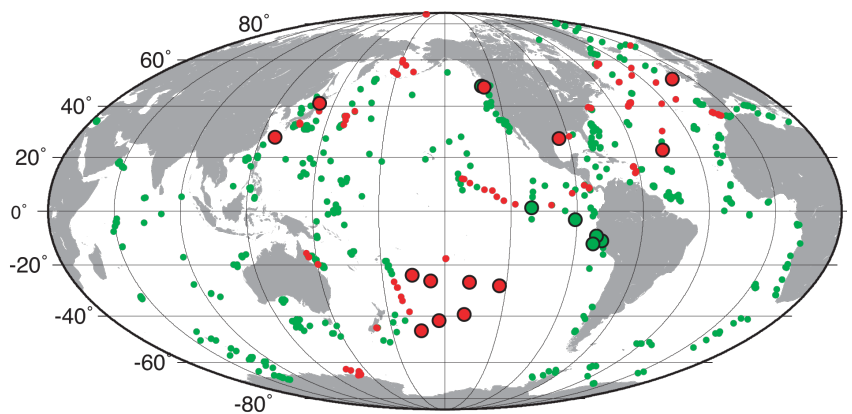

Figure 2. Combined ODP (green circles) and IODP (red circles) drill sites map. Larger symbols show sites where a complete and well-documented microbiological sampling campaign was adopted. For reference, these are sites 1225-1231, 1244, 1245, 1249-1251, C0013-C0016, C0020, U1301, U1316-1318, U1320, U1324, U1362, U1365-U1371, and U1382-U1384.

tional archived resources, and advanced training of technicians have been presented to IODP and ship operators in the past without full implementation (for example, SPC (Science Planning Committee) Consensuses 808-10, 808-11, 80812 , and 808-15). Therefore, for the success of future biosphere explorations, a revised recommendation from the subsurface community, including new techniques and technologies, should be crafted and presented to coincide with the start of the new International Ocean Discovery Program. To facilitate biological sampling and processing, advanced training of current technicians or ideally a microbiology-specific technician sailing on each expedition will be recommended. While all of these recommendations represent a substantial step forward, it is noted that in the new science plan, a quarter of the objectives are directly associated with biological research, with many of the other objectives reliant upon biological data. We must, therefore, strive for implementation of our new plan for biological exploration. The involvement of the NSF (National Science Foundation), along with IODP directors, curators, and technicians, is seen as the best course of action. Efforts are underway to complete this task, with a formal recommendation scheduled as early as 2014 .

\section{Workshop participants}

Jan Amend (coorganizer), Heath Mills (coorganizer), Beth N. Orcutt (coorganizer), Karine Alain, Marco Blöthe, Steve D'Hondt, Jiasong Fang, Gretchen Früh-Green, Kai-Uwe Hinrichs, Tatsuhiko Hoshino, Akira Ijiri, Fumio Inagaki, Yusuke Kubo, Jessica Labonte, Doug LaRowe, Karen Lloyd, Yuki Morono, Bill Orsi, Brandi Kiel Reese, Susumu Sakata, Justine Sauvage, Axel Schippers, Fengping Wang, Xiang Xiao. 
Acknowledgements. The meeting organizers would like to thank Ines Bala and John Emmittee of IODP-MI for their help in organizing workshop logistics, and Wolfgang Bach and Fengping Wang for help in developing the proposal and agenda for this workshop. This is C-DEBI contribution number 200.

Edited by: T. Morishita

Reviewed by: two anonymous referees

\section{References}

Arndt, S., Brumsack, H. J., and Wirtz, K. W.: Cretaceous black shales as active bioreactors: A bigeochemical model for the deep biosphere encountered during odp leg 207 (demerara rise), Geochim. Cosmochim. Ac., 70, 408-425, 2006.

Bach, W. and Edwards, K. J.: Iron and sulfide oxidation within the basaltic ocean crust: Implications for chemolithoautotrophic microbial biomass production, Geochim. Cosmochim. Ac., 67, 3871-3887, 2003.

Biddle, J. F., House, C. H., and Brenchley, J. E.: Microbial stratification in deeply buried marine sediment reflects changes in sulfate/methane profiles, Geobiology, 3, 287-295, 2005.

Biddle, J. F., Lipp, J. S., Lever, M., Lloyd, K. G., Sørensen, K. B., Anderson, K., Fredricks, H. F., Elvert, M., Kelly, T. J., Schrag, D. P., Sogin, M. L., Brenchley, J. E., Teske, A., House, C. H., and Hinrichs, K.-U.: Heterotrophic archaea dominate sedimentary subsurface ecosystems off peru, P. Natl. Acad. Sci. USA, 103, 3846-3851, 2006.

Biddle, J. F., Fitz-Gibbon, S., Schuster, S. C., Brenchley, J. E., and House, C. H.: Metagenomic signatures of the peru margin subseafloor biopshere show a genetically distinct environment, P. Natl. Acad. Sci. USA, 105, 10583-10588, 2008.

Blair, C. C., D’Hondt, S., Spivack, A. J., and Kingsley, R. H.: Radiolytic hydrogen and microbial respiration in subsurface sediments, Astrobiology, 7, 951-970, 2007.

D'Hondt, S., Rutherford, S., and Spivack, A. J.: Metabolic activity of subsurface life in deep-sea sediments, Science, 295, 20672070, 2002.

D’Hondt, S., Jørgensen, B. B., Miller, D. J., Batzke, A., Blake, R., Cragg, B. A., Cypionka, H., Dickens, G. R., Ferdelman, T., Hinrichs, K. U., Holm, N. G., Mitterer, R., Spivack, A., Wang, G. Z., Bekins, B., Engelen, B., Ford, K., Gettemy, G., Rutherford, S. D., Sass, H., Skilbeck, C. G., Aiello, I. W., Guerin, G., House, C. H., Inagaki, F., Meister, P., Naehr, T., Niitsuma, S., Parkes, R. J., Schippers, A., Smith, D. C., Teske, A., Wiegel, J., Padilla, C. N., and Acosta, J. L. S.: Distributions of microbial activities in deep subseafloor sediments, Science, 306, 2216-2221, 2004.

D’Hondt, S., Spivack, A., Pockalny, R., Ferdelman, T., Fischer, J., Kallmeyer, J., Abrams, L., Smith, D. C., Graham, D., Hasiuk, F., Rogers, J., Schrum, H., and Stancin, A.: Subseafloor sedimentary life in the south pacific gyre, P. Natl. Acad. Sci. USA, 106, 11651-11656, 2009.

Edgcomb, V. P., Beaudoin, D., Gast, R. J., Biddle, J. F., and Teske, A.: Marine subsurface eukaryotes: The fungal majority, Environ. Microbiol., 13, 172-183, 2011.

Inagaki, F., Kuypers, M. M. M., Tsunogai, U., Ishibaski, J.-i., Nakamura, K.-i., Treude, T., Ohkubo, S., Nakaseama, M., Gena, K., Chiba, H., Hirayama, H., Nunoura, T., Takai, K., Jørgensen, B. B., Horikoshi, K., and Boetius, A.: Microbial community in a sediment-hosted $\mathrm{CO}_{2}$ lake of the southern okinawa trough hydrothermal system, P. Natl. Acad. Sci. USA, 103, 14164-14169, 2006.

IODP: Science plan for 2013-2023: Illuminating earth's past, present and future, Integrated Ocean Drilling Program Management International, Washington DC, 2011.

Jørgensen, B. B.: Deep subseafloor microbial cells on physiological standby, P. Natl. Acad. Sci. USA, 108, 18193-18194, 2011.

Joye, S. B., Samarkin, V. A., Orcutt, B. N., MacDonald, I. R., Hinrichs, K.-U., Elvert, M., Teske, A., Lloyd, K. G., Lever, M., Montoya, J. P., and Meile, C.: Metabolic variability in seafloor brines revealed by carbon and sulphur dynamics, Nat. Geosci., 2, 249354, 2009.

Kallmeyer, J., Pockalny, R., Adhikari, R. R., Smith, D. C., and D'Hondt, S.: Global distribution of microbial abundance and biomass in subseafloor sediment, P. Natl. Acad. Sci. USA, 109, 16213-16216, 2012.

LaRowe, D. E. and Amend, J. P.: Energetic constraints on life in marine deep sediments, in: Life in extreme environments: Microbial life in the deep biosphere, edited by: Kallmeyer, J. and Wagner, D., de Gruyter, in press, 2014.

LaRowe, D. E., Dale, A. W., and Regnier, P.: A thermodynamic analysis of the anaerobic oxidation of methane in marine sediments, Geobiology, 6, 436-449, 2008.

LaRowe, D. E., Dale, A. W., Aguilera, D. R., L'Heureux, I., Amend, J. P., and Regnier, P.: Modeling microbial reaction rates in a submarine hydrothermal vent chimney wall, Geochim. Cosmochim. Ac., in press, 2014.

Lever, M. A., Alperin, M. J., Teske, A., Heuer, V., Schmidt, F., Hinrichs, K. U., Morono, Y., Masui, N., and Inagaki, F.: Acetogenesis in deep subseafloor sediments of the juan du fuca ridge flank: A synthesis of geochemical, thermodynamic, and gene-based evidence, Geomicrobiol. J., 27, 183-211, 2010.

Lever, M. A., Rouxel, O. J., Alt, J. C., Shimizu, N., Ono, S., Coggon, R. M., Shanks III, W. C., Lapham, L., Elvert, M., Prieto Mollar, X., Hinrichs, K. U., Inagaki, F., and Teske, A.: Evidence for microbial carbon and sulfur cycling in deeply buried ridge flank basalt, Science, 339, 1305-1308, 2013.

Lloyd, K. G., Schreiber, L., Petersen, D. G., Kjeldsen, K. U., Lever, M. A., Steen, A. D., Stepanauskas, R., Richter, M., Kleindienst, S., Lenk, S., Schramm, A., and Jørgensen, B. B.: Predominant archaea in marine sediments degrade detrital proteins, Nature, 496, 213-216, 2013.

Lomstein, B. A., Langerhuus, A. T., D’Hondt, S., Jørgensen, B. B., and Spivack, A. J.: Endospore abundance, microbial growth and necromass turnover in deep sub-seafloor sediment, Nature, 484, 101-104, 2012.

Mason, O. U., Nakagawa, T., Rosner, M., Van Nostrand, J. D., Zhou, J., Maruyama, A., Fisk, M. R., and Giovannoni, S. J.: First investigation of the microbiology of the deepest layer of ocean crust, PLoS ONE, 5, e15399, doi:10/1037/journal.pone.0015399, 2010.

Mills, H. J., Reese, B. K., and St. Peter, R. C.: Characterization of microbial population shifts during sample storage, Frontiers in Microbiology, 3, 49, doi:10.3389/fmicb.2012.00049, 2012.

Morono, Y., Terada, T., Nishizawa, M., Ito, M., Hillion, F., Takahata, N., Sano, Y., and Inagaki, F.: Carbon and nitrogen assimilation in deep subseafloor microbial cells, P. Natl. Acad. Sci. USA, 108, 18295-18300, 2011. 
Orcutt, B. N., Sylvan, J. B., Knab, N. J., and Edwards, K. J.: Microbial ecology of the dark ocean above, at, and below the seafloor, Microbiol. Mol. Biol. R., 75, 361-422, 2011.

Orcutt, B. N., Wheat, C. G., Rouxel, O. J., Hulme, S., Edwards, K. J., and Bach, W.: Oxygen consumption rates in subseafloor basaltic crust derived from a reaction transport model, Nature Communications, 4, 2539, doi:10.1038/ncomms3539, 2013.

Orsi, W., Biddle, J. F., and Edgcomb, V. P.: Deep sequencing of subseafloor eukaryotic rrna reveals active fungi across marine subsurface provinces, PLoS ONE, 8, e56335, doi:10.1038/ncomms3539, 2013a.

Orsi, W. D., Edgcomb, V. P., Christman, G. D., and Biddle, J. F.: Gene expression in the deep biosphere, Nature, 2013b.

Parkes, R. J., Webster, G., Cragg, B. A., Weightman, A. J., Newberry, C. J., Ferdelman, T. G., Kallmeyer, J., Jørgensen, B. B., Aiello, I. W., and Fry, J. C.: Deep sub-seafloor prokaryotes stimulated at interfaces over geologic time, Nature, 436, 390-394, 2005.

Røy, H., Kallmeyer, J., Adhikar, R. R., Pockalny, R., Jørgensen, B. B., and D'Hondt, S.: Aerobic microbial respiration in 86-millionyear-old deep-sea red clay, Science, 336, 922-925, 2012.
Schippers, A., Neretin, L. N., Kallmeyer, J., Ferdelman, T. G., Cragg, B. A., Parkes, R. J., and Jørgensen, B. B.: Prokaryotic cells of the deep sub-seafloor biosphere identified as living bacteria, Nature, 433, 861-864, 2005.

Schrum, H. N., Spivack, A. J., Kastner, M., and D'Hondt, S.: Sulfate-reducing ammonium oxidation: A thermodynamically feasible metabolic pathway in subseafloor sediment, Geology, 37, 939-942, 2009.

Wang, G., Spivack, A. J., Rutherford, S. D., Manor, U., and D'Hondt, S.: Quantification of co-occurring reactions rates in deep subseafloor sediments, Geochim. Cosmochim. Ac., 72, 3479-3488, 2008

Wang, G., Spivack, A. J., and D'Hondt, S.: Gibbs energies of reaction and microbial mutualism in anaerobic deep subseafloor sediments of odp site 1226, Geochim. Cosmochim. Ac., 74, 3938 $3947,2010$. 